\title{
Enhancing thermotolerance of tomato plants (Lycopersieon esculentum Mill.) by heat hardening of seeds
}

\author{
Sohair K. Ibrahim ${ }^{1 *}$ and Lulwa A. El- Muqadam²
}

\begin{abstract}
Background: High temperature is a crucial problem in growing good crops of high temperature sensitive vegetables including tomato. Therefore, this study was carried out to investigate the effects of pre-sowing heat treatments of tomato seeds on germination, growth and biochemical changes of the plants grown under high temperature stress.
\end{abstract}

Material and methods: The study included two experiments; experiment I dealt with the effect of pre-sowing heat hardening of tomato (Lycopersiecon esculentum Mill. cV. Marmand VF) for different periods of soaking at $25^{\circ} \mathrm{C}$ for 5 min, $3 \mathrm{~h}$ and $6 \mathrm{~h}$ before exposing to $50^{\circ} \mathrm{C}, 60^{\circ} \mathrm{C}$ and $70^{\circ} \mathrm{C}$ for $0.5 \mathrm{~h}, 1 \mathrm{~h}$ and $2 \mathrm{~h}$.

Results: Best results represented by germination parameters were obtained by soaking the seeds for 5 min before exposure to $50^{\circ} \mathrm{C}, 60^{\circ} \mathrm{C}$ and $70^{\circ} \mathrm{C}$ for $0.5 \mathrm{~h}, 1 \mathrm{~h}$ and $2 \mathrm{~h}$. According to the germination data, these treatments were chosen to study their effect on vegetative growth as well as some biochemical parameters (experiment II). The study showed that seed hardening increased growth criteria expressed by stem length, number of branches, number and area of leaves and fresh and dry weight of shoots. The same treatments increased photosynthetic pigments, i.e. (chlorophylls "a" and "b") and carotenoids of tomato leaves as well as the studied chemical constituents of shoots (reducing sugars, sucrose, amino acids, proline and proteins as well as nucleic acids and saturated fatty acids. Maximum response was attained by treatment with $60^{\circ} \mathrm{C}$ for $1 \mathrm{~h}$ and $2 \mathrm{~h}$.

Conclusion: Thus, these treatments can help the plant to cope with the adverse effects of high temperature prevailing during their growth stage.

Keywords: Tomato, Seed hardening, High temperature stress, Growth, Metabolism

\section{Introduction}

Tomato (Lycopersicon esculentum Mill.) is one of the widely grown vegetable crops. It is an important crop for human consumption.

It is usually cultivated in the open field in Saudi Arabia during September as the prevailing temperature is suitable for growth and development of the plant. Tomato plants grow rapidly, so extending the season and increasing continuity of supply can be achieved by sowing the seeds during spring. However, the plants exhibited to high temperature during their growth and development.

\footnotetext{
* Correspondence: sohair.k@hotmail.com

'Department of Botany, National Research Centre, Dokki, Cairo, Egypt

Full list of author information is available at the end of the article
}

High temperature is a crucial problem in growing good crops of high temperature sensitive vegetables including tomato. It impairs different morphological criteria (Khalil and Moursy 1983 and Warrag 1999). High temperature affects wide spectrum of both biochemical and physiological responses within the plant cell. These results are expected and described by many researchers especially in the case of growing organs, since all the reactions in the plant already take place rapidly and further rise in temperature might easily disturb the balance (Fisher 1980). Other investigators reported that extreme and variation of high temperature can damage the intermolecular interactions needed for growth (Bita and Gerats 2013). 
Protection of plants from high temperature stress can be achieved by several mechanisms; one of these mechanisms is seed hardening; it is a physiological seed enhancement method (Taylor et al. 1998). Seed hardening can be achieved by pre-sowing treatments in which the seeds are soaked in water, an osmotic solution or growth regulators as well as exposing the seeds to elevated temperature above the maximum temperature prevailing during their growth. These treatments allow the seeds to go to the first stages of germination but not permit radicale protrusion through the seed coat (Heydeker 1977). Planting hardened seeds in the field gives the plant a better start than the non-hardened plants. Thus, hardened plants might survive adverse environmental stresses like high temperature more easily because of the advanced state of development.

The present study is an additional contribution for understanding the effects of pre-sowing heat treatments of tomato seeds on germination, growth and biochemical changes of the plant grown under high temperature stress $\left(30-40^{\circ} \mathrm{C}\right)$.

\section{Material and methods}

The study comprised of two experiments; the planning of the second experiment depended on the results of the first one according to the following order:

\section{Experiment I: germination tests}

Uniform seeds of tomato (Lycopersicon esculentum Mill. cv. Marmand VF) were soaked in water at $25^{\circ} \mathrm{C}$ for 5 min, $3 \mathrm{~h}$ and $6 \mathrm{~h}$ and dried quickly within two layers of filter paper, and each group was divided to two sets. The first set from each group was weighed then dried at $105^{\circ} \mathrm{C}$ till constant weight according to Hart and Neustadt (1957) to measure moisture content that reached $20.6 \%, 44.33 \%$ and $63.52 \%$, respectively. The second set from each group was subjected to 50,60 and $70{ }^{\circ} \mathrm{C}$ for $0.5 \mathrm{~h}, 1 \mathrm{~h}$ and $2 \mathrm{~h}$. The seeds were germinated at $25^{\circ} \mathrm{C}$ in Petri dishes each contained 20 seeds.

Ten replicates were allotted for each treatment as well as control treatment (seeds soaked for $0.5 \mathrm{~h}, 1 \mathrm{~h}$ or $3 \mathrm{~h}$ at room temperature $\left(25^{\circ} \mathrm{C}\right)$. Germination was recorded for 8 days, and then germination data were recorded as follows: germination capacity, radical and hypocotyl length as well as radical fresh weight and seedling fresh weight.

\section{Experiment II}

The previous experiment results indicated that the best results were obtained and the seeds were then soaked for $5 \mathrm{~min}$ (moisture content 20.6\%) and exposed to for $50{ }^{\circ} \mathrm{C}, 60^{\circ} \mathrm{C}$ and $70^{\circ} \mathrm{C}$ for $0.5 \mathrm{~h}, 1 \mathrm{~h}$ and $2 \mathrm{~h}$ as well as seeds soaked for $5 \mathrm{~min}$ only as (control). These treatments were chosen to study their effect on vegetative growth and some biochemical parameters.

\section{Growing technique and sampling}

Tomato seeds were sown on March in JV (7) cubes, and when the seeds were attained 30 days, they were transferred to $30 \mathrm{~cm}$ in diameter pots filled with equal amounts of soil (consisted of clay + paet moss + perlite at the ratio of 1:3:5 $(w / w)$. Fertilization was applied as the recommended dose $(5 \mathrm{~g}$ superphosphate, $10 \mathrm{~g}$ mixture of ammonium sulphate and potassium sulphate at the ratio of 3:2) for each pot.

The plants were supplied with water according to their requirements which was governed by climatic conditions. The experiment was carried outdoors in the screen of the Girls College of Science, Damman, Saudi Arabia, for two successive seasons. The maximum and minimum temperatures as well as relative humidity are shown in Table 1.

Samples were collected at random 30 days after transplanting (DAT). Each treatment was divided into three replicates for recording vegetative characters as well as chemical analysis.

\section{Biochemical analysis}

Photosynthetic pigments [chlorophyll a, chlorophyll b and carotenoids (car)] were determined in fresh leaves (Metzner et al. 1965).

\section{The following parameters were estimated in dry shoots at} $70^{\circ} \mathrm{C}$

Reducing sugars, sucrose and polysaccharides were measured according to (Dubios et al. 1956). Total amino acids were analysed according to Boulter and Barber (1963). Protein extraction followed Anderson and Beardall (1991) and estimated as described by Lowry et al. (1951).

Proline, nucleic acids and fatty acids were determined in fresh shoots. Proline was measured according to Troll and Lidsley (1955). Nucleic acids were extracted according to Schmidt and Thaunhauser (1945), and ribonucleic acid (RNA) and deoxyribonucleic acid (DNA) were estimated according to the method of Winzler (1955) and Burton (1956), respectively.

Fatty acids were analysed through four successive steps: (1) extraction by petroleum ether $60-40{ }^{\circ} \mathrm{C}$, (2) saponification with $\mathrm{NaOH}(20 \%)$, (3) methylation by methyl alcohol and (4) identification by GLC (Varian Model 6000 chromatography). The GLC condition was as follows: The glass column filled with $15 \%$ DEGS. The column oven temperature was programmed at $6{ }^{\circ} \mathrm{C} / \mathrm{min}$ from $80^{\circ} \mathrm{C}$ to $130^{\circ} \mathrm{C}$ and kept finally for $25 \mathrm{~min}$. Injector and detector temperatures were $220^{\circ} \mathrm{C}$ and $260^{\circ} \mathrm{C}$, respectively. Gases' flow rates were 30,30 and $300 \mathrm{~cm} / \mathrm{min}$ for N2, H2 and air, respectively. The flow rate inside the column was adjusted as $1 \mathrm{ml} / \mathrm{min}$. 
Table 1 Average of monthly maximum and minimum air temperature and relative humidity during the two seasons of study

\begin{tabular}{|c|c|c|c|c|c|c|c|c|}
\hline \multirow[t]{3}{*}{ Month } & \multicolumn{4}{|l|}{ 1st season } & \multicolumn{4}{|c|}{ 2nd season } \\
\hline & \multicolumn{2}{|c|}{ Temperature } & \multicolumn{2}{|c|}{ Relative humidity \% } & \multicolumn{2}{|c|}{ Temperature } & \multicolumn{2}{|c|}{ Relative humidity \% } \\
\hline & Maximum & Minimum & Maximum & Minimum & Maximum & Minimum & Maximum & Minimum \\
\hline March & 30 & 10 & 95 & 17 & 30 & 11 & 95 & 20 \\
\hline April & 38 & 14 & 85 & 10 & 36 & 14 & 95 & 17 \\
\hline May & 43 & 16 & 98 & 3 & 44 & 18 & 90 & 8 \\
\hline
\end{tabular}

\section{Statistical analysis}

The data of the first experiment was subjected to statistical analysis according to the analysis of variance with interaction. The values of the least significant difference (LSD) were calculated at 5\% level of probability.

The data of the second experiment was arranged in complete randomized design. The obtained data were statistically analysed according to Duncan (1955) at the probability of $5 \%$. Mean value followed by the same letter within each column is not significant.

By applying the Steel and Torrie (1966) test, the results showed the same trend. Therefore, the combined analysis of the two seasons was calculated. The combined analysis of the two seasons was calculated after Steel and Torrie (1966) as the results obtained showed the same trend.

\section{Results}

Germination percentage (Table 2) showed the optimum values as the seeds soaked for $5 \mathrm{~min}, 3 \mathrm{~h}$ and $6 \mathrm{~h}$ at room temperature compared to the other treatments at the different degrees $\left(50,60\right.$ and $70{ }^{\circ} \mathrm{C}$ ). Moreover, these treatments decreased germination percentage by increasing the degree of temperature from $50 \rightarrow 60 \rightarrow$ $70{ }^{\circ} \mathrm{C}$ as well as prolonging the period of soaking from 5 $\min \rightarrow 3 \mathrm{~h} \rightarrow 6 \mathrm{~h}$. The lowest value of germination percentage was obtained by soaking the seeds for $3 \mathrm{~h}$ or $6 \mathrm{~h}$ before exposure for $70^{\circ} \mathrm{C}$ for any period of exposure. Thus, the seeds did not tolerate the high percentage of moisture content concomitant to high temperature.

Results in Table 3 revealed the interaction of the soaking period of the seeds and the period of exposure to different degrees of temperature on the radicale length; their length significantly increased by exposing the seeds to $50^{\circ} \mathrm{C}$ or $60^{\circ} \mathrm{C}$ for all exposure periods after soaking the seeds for 5 min. However, soaking the seeds for $6 \mathrm{~h}$ before exposing to $70{ }^{\circ} \mathrm{C}$ at all used periods decreased significantly the length of radicale as compared to control.

Hypocotyl length significantly increased by soaking tomato seeds for $5 \mathrm{~min}$ before exposing to the different used periods at $50{ }^{\circ} \mathrm{C}$. On the other hand, increasing the period of soaking to $3 \mathrm{~h}$ and $6 \mathrm{~h}$ accompanied with elevating the exposure temperature to $60^{\circ} \mathrm{C}$ or $70{ }^{\circ} \mathrm{C}$ significantly decreased hypocotyl length. Maximum significant decrease was reached by soaking the seeds for $3 \mathrm{~h}$ or $6 \mathrm{~h}$ before exposing to different periods at $70^{\circ} \mathrm{C}$ (Table 2).

Radicale fresh weight did not show any significant increase due to treatments. In addition, significant decrease was obtained by soaking the seeds for $3 \mathrm{~h}$ or $6 \mathrm{~h}$ before exposing to $60{ }^{\circ} \mathrm{C}$ or $70{ }^{\circ} \mathrm{C}$ for all exposure periods (Table 3 ).

Table 2 Effect of seed hardening on germination percentage, radicale length $(\mathrm{cm})$ and hypocotyl length $(\mathrm{cm})$

\begin{tabular}{|c|c|c|c|c|c|c|c|c|c|c|}
\hline \multicolumn{2}{|c|}{ Treatment } & \multirow{2}{*}{\multicolumn{3}{|c|}{$\frac{\text { Germination } \%}{\text { Period of soaking }}$}} & \multirow{2}{*}{\multicolumn{3}{|c|}{$\begin{array}{l}\text { Radicale length }(\mathrm{cm}) \\
\text { Period of soaking }\end{array}$}} & \multirow{2}{*}{\multicolumn{3}{|c|}{$\frac{\text { Hypocotyl length }(\mathrm{cm})}{\text { Period of soaking }}$}} \\
\hline \multirow{2}{*}{$\begin{array}{l}\text { Temp } \\
\left({ }^{\circ} \mathrm{C}\right)\end{array}$} & \multirow{2}{*}{$\begin{array}{l}\text { Exposure } \\
\text { period } \\
\text { (h) }\end{array}$} & & & & & & & & & \\
\hline & & $5 \mathrm{~min}$ & $3 \mathrm{~h}$ & $6 \mathrm{~h}$ & $5 \mathrm{~min}$ & $3 \mathrm{~h}$ & $6 \mathrm{~h}$ & $5 \mathrm{~min}$ & $3 \mathrm{~h}$ & $6 \mathrm{~h}$ \\
\hline \multicolumn{2}{|l|}{ Control } & 99.8 & 99.5 & 99.4 & 4.17 & 4.37 & 4.30 & 11.90 & 12.00 & 11.13 \\
\hline \multirow[t]{3}{*}{50} & 0.5 & 99.4 & 95.4 & 96.1 & 5.13 & 4.80 & 4.60 & 13.03 & 12.40 & 11.63 \\
\hline & 1 & 98.0 & 92.8 & 92.7 & 5.33 & 5.03 & 4.50 & 12.65 & 11.40 & 11.17 \\
\hline & 2 & 97.8 & 89.2 & 80.5 & 4.67 & 4.63 & 4.93 & 13.03 & 12.07 & 11.70 \\
\hline \multirow[t]{3}{*}{60} & 0.5 & 99.6 & 77.4 & 74.0 & 5.23 & 4.57 & 4.70 & 11.80 & 12.20 & 10.13 \\
\hline & 1 & 97.4 & 75.2 & 61.0 & 5.47 & 4.23 & 4.23 & 12.23 & 11.80 & 10.17 \\
\hline & 2 & 95.6 & 68.8 & 61.5 & 5.47 & 4.20 & 4.17 & 12.03 & 11.50 & 10.13 \\
\hline \multirow[t]{3}{*}{70} & 0.5 & 91.8 & 55.4 & 52.2 & 4.70 & 4.07 & 3.53 & 12.13 & 10.50 & 10.13 \\
\hline & 1 & 84.9 & 51.5 & 50.4 & 4.63 & 3.90 & 3.10 & 11.70 & 8.50 & 8.63 \\
\hline & 2 & 85.5 & 49.9 & 50.6 & 4.66 & 3.20 & 3.13 & 10.73 & 8.13 & 7.47 \\
\hline \multicolumn{2}{|c|}{ LSD of interaction } & - & & & 0.49 & & & 0.72 & & \\
\hline
\end{tabular}


Table 3 Effect of seed hardening on radicale fresh weight (g/ plant) and seedling fresh weight (g/plant)

\begin{tabular}{|c|c|c|c|c|c|c|c|}
\hline \multicolumn{2}{|c|}{ Treatment } & \multirow{2}{*}{\multicolumn{3}{|c|}{$\begin{array}{l}\text { Radicale fresh wt. (g/ } \\
\text { plant) }\end{array}$}} & \multirow{2}{*}{\multicolumn{3}{|c|}{$\begin{array}{l}\text { Seedling fresh wt. (g/ } \\
\text { plant) }\end{array}$}} \\
\hline \multirow{2}{*}{$\begin{array}{l}\text { Temp } \\
\left({ }^{\circ} \mathrm{C}\right)\end{array}$} & \multirow{2}{*}{$\begin{array}{l}\text { Exposure } \\
\text { period } \\
\text { (h) }\end{array}$} & & & & & & \\
\hline & & $5 \mathrm{~min}$ & $3 \mathrm{~h}$ & $6 \mathrm{~h}$ & $5 \mathrm{~min}$ & $3 \mathrm{~h}$ & $6 \mathrm{~h}$ \\
\hline \multicolumn{2}{|l|}{ Control } & 0.001 & 0.011 & 0.012 & 0.081 & 0.080 & 0.080 \\
\hline \multirow[t]{3}{*}{50} & 0.5 & 0.012 & 0.011 & 0.012 & 0.085 & 0.077 & 0.077 \\
\hline & 1 & 0.012 & 0.011 & 0.011 & 0.087 & 0.075 & 0.077 \\
\hline & 2 & 0.012 & 0.011 & 0.011 & 0.082 & 0.072 & 0.072 \\
\hline \multirow[t]{3}{*}{60} & 0.5 & 0.012 & 0.010 & 0.011 & 0.087 & 0.073 & 0.074 \\
\hline & 1 & 0.012 & 0.009 & 0.010 & 0.088 & 0.074 & 0.072 \\
\hline & 2 & 0.012 & 0.009 & 0.009 & 0.083 & 0.070 & 0.069 \\
\hline \multirow[t]{3}{*}{70} & 0.5 & 0.011 & 0.009 & 0.008 & 0.084 & 0.055 & 0.051 \\
\hline & 1 & 0.011 & 0.008 & 0.008 & 0.082 & 0.056 & 0.051 \\
\hline & 2 & 0.011 & 0.007 & 0.007 & 0.082 & 0.055 & 0.050 \\
\hline \multicolumn{2}{|c|}{ LSD of interaction } & \multicolumn{3}{|l|}{0.001} & \multicolumn{3}{|l|}{0.003} \\
\hline
\end{tabular}

Seedling fresh weight exhibited significant increase by soaking the seeds for $5 \mathrm{~min}$ before exposing to $50^{\circ} \mathrm{C}$ or $60^{\circ} \mathrm{C}$ for $0.5 \mathrm{~h}$ or $1 \mathrm{~h}$. However, prolonging the period of soaking to $3 \mathrm{~h}$ and $6 \mathrm{~h}$ before exposing the seeds to different temperature degrees for all used periods of exposure $(0.5 \mathrm{~h}, 1 \mathrm{~h}$ and $2 \mathrm{~h})$ showed an opposite trend as all treatments decreased the fresh weight of the seedling (Table 3).

\section{Growth responses}

The studied parameters of growth were shown in Table 4. Stem length of tomato plants showed an increase by exposing the seed for $60^{\circ} \mathrm{C}$ or $70^{\circ} \mathrm{C}$. Significant increments were attained by treatment of $60{ }^{\circ} \mathrm{C}$ for $2 \mathrm{~h}$ or $70^{\circ} \mathrm{C}$ for $0.5 \mathrm{~h}$.
The number of branches significantly increased by all treatment seeds at $50^{\circ} \mathrm{C}$ for $0.5 \mathrm{~h}$, and the highest number of branches obtained by treatment at $60^{\circ} \mathrm{C}$ as well as treatment at $70{ }^{\circ} \mathrm{C}$ for $0.5 \mathrm{~h}$. Maximum significant increase attained by exposing the seeds to $60^{\circ} \mathrm{C}$ for $1 \mathrm{~h}$ or $2 \mathrm{~h}$.

The number of leaves significantly increased by treatment at $50^{\circ} \mathrm{C}$ for $1 \mathrm{~h}$ or $2 \mathrm{~h}$ and $60^{\circ} \mathrm{C}$ for all periods of exposure.

The area and fresh weight of leaves increased significantly by all treatments with the exception of seeds by treatment at $70^{\circ} \mathrm{C}$ for $2 \mathrm{~h}$. Maximum increase was attained by treating the seeds for $2 \mathrm{~h}$ at $60^{\circ} \mathrm{C}$. The dry weight of leaves followed almost the same trend but the increase with the treatment at $50{ }^{\circ} \mathrm{C}$ for 0.5 was not significant (Table 4).

Shoot fresh weight showed a significant increase with all treatments except treating the seeds at $70^{\circ} \mathrm{C}$ for $2 \mathrm{~h}$.

Shoot dry weight followed the same pattern of changes shown in the case of fresh weight. Meanwhile, the increase with treatment at $50^{\circ} \mathrm{C}$ for $0.5 \mathrm{~h}$ was not significant (Table 4).

\section{Biochemical analyses}

Results recorded in Table 5 show the effect of hardening on photosynthetic pigments and the studied carbohydrate fractions. Chlorophylls a significantly increased with all treatments except those exposed to $50^{\circ} \mathrm{C}$ for 0.5 $\mathrm{h}$. The maximum increase was given by exposing the seeds to $60^{\circ} \mathrm{C}$ for $2 \mathrm{~h}$ followed by treatments at $60^{\circ} \mathrm{C}$ or $70^{\circ} \mathrm{C}$ for $1 \mathrm{~h}$. Chlorophylls b content significantly increased with treatment at $60^{\circ} \mathrm{C}$ for $2 \mathrm{~h}$ and $70^{\circ} \mathrm{C}$ for all used exposure periods. Total chlorophylls $(\mathrm{a}+\mathrm{b})$ showed a significant increase by all hardening treatments except $50{ }^{\circ} \mathrm{C}$ or $60^{\circ} \mathrm{C}$ for $0.5 \mathrm{~h}$.

Table 4 Effect of seed hardening on vegetative growth

\begin{tabular}{|c|c|c|c|c|c|c|c|c|c|}
\hline \multicolumn{2}{|c|}{ Treatments } & \multicolumn{8}{|c|}{ Parameters } \\
\hline $\begin{array}{l}\text { Temp. } \\
\left({ }^{\circ} \mathrm{C}\right)\end{array}$ & $\begin{array}{l}\text { Exposure } \\
\text { period (h) }\end{array}$ & $\begin{array}{l}\text { Stem } \\
\text { length } \\
(\mathrm{cm})\end{array}$ & $\begin{array}{l}\text { No. of } \\
\text { branches/ } \\
\text { plant }\end{array}$ & $\begin{array}{l}\text { No. of } \\
\text { leaves/plant }\end{array}$ & $\begin{array}{l}\text { Leaf area } \\
\left.\text { ( } \mathrm{cm}^{2} / \text { plant }\right)\end{array}$ & $\begin{array}{l}\text { Leaves fresh wt. } \\
\text { (g/plant) }\end{array}$ & $\begin{array}{l}\text { Leaves dry wt. } \\
\text { (g/plant) }\end{array}$ & $\begin{array}{l}\text { Shoot Fresh wt. } \\
\text { (g/plant) }\end{array}$ & $\begin{array}{l}\text { Shoot dry wt. } \\
\text { (g/plant) }\end{array}$ \\
\hline \multicolumn{2}{|l|}{ Control } & $36.5^{b}$ & $0.67^{d}$ & $6.33^{c}$ & $199.27^{e}$ & $6.01^{9}$ & $0.691^{d}$ & $11.76^{\mathrm{e}}$ & $1.41^{\mathrm{ef}}$ \\
\hline \multirow[t]{3}{*}{50} & 0.5 & $35.1^{b}$ & $0.67^{d}$ & $6.67^{c}$ & $229.10^{b c}$ & $6.51^{f}$ & $0.714^{\mathrm{cd}}$ & $12.52^{d}$ & $1.44^{\text {de }}$ \\
\hline & 1 & $36.0^{\mathrm{b}}$ & $1.00^{c}$ & $7.67^{\mathrm{ab}}$ & $238.70^{b}$ & $6.76^{\mathrm{ef}}$ & $0.743^{\mathrm{bc}}$ & $13.20^{c}$ & $1.48^{\mathrm{cd}}$ \\
\hline & 2 & $37.7^{\mathrm{b}}$ & $1.33^{b}$ & $8.33^{b}$ & $239.70^{b}$ & $7.18^{\mathrm{cd}}$ & $0.779^{b}$ & $13.53^{c}$ & $1.51^{b c}$ \\
\hline \multirow[t]{3}{*}{60} & 0.5 & $36.5^{b}$ & $1.00^{c}$ & $7.67^{c}$ & $215.90^{c d}$ & $7.02^{\text {de }}$ & $0.764^{b}$ & $13.69^{c}$ & $1.49^{\mathrm{cd}}$ \\
\hline & 1 & $36.9^{\mathrm{ab}}$ & $1.00^{c}$ & $8.00^{c}$ & $287.40^{\mathrm{a}}$ & $7.65^{\mathrm{ab}}$ & $0.764^{b}$ & $14.79^{b}$ & $1.51^{b c}$ \\
\hline & 2 & $39.3^{a}$ & $1.67^{\mathrm{a}}$ & $8.33^{\mathrm{a}}$ & $279.00^{\mathrm{a}}$ & $7.95^{\mathrm{a}}$ & $0.829^{a}$ & $15.77^{a}$ & $1.63^{\mathrm{a}}$ \\
\hline \multirow[t]{3}{*}{70} & 0.5 & $39.0^{\mathrm{a}}$ & $1.33^{\mathrm{b}}$ & $7.67^{b}$ & $252.0^{\mathrm{b}}$ & $7.46^{\mathrm{bc}}$ & $0.774^{b}$ & $14.78^{\mathrm{b}}$ & $1.54^{\mathrm{b}}$ \\
\hline & 1 & $37.4^{\mathrm{ab}}$ & $1.00^{c}$ & $7.00^{c}$ & $220.00^{c d}$ & $7.73^{\mathrm{ab}}$ & $0.723^{c}$ & $13.74^{c}$ & $1.47^{c d}$ \\
\hline & 2 & $37.1^{\mathrm{ab}}$ & $1.00^{c}$ & $6.67^{c}$ & $208.30^{\text {de }}$ & $6.10^{\mathrm{g}}$ & $0.683^{d}$ & $12.05^{\text {de }}$ & $1.36^{f}$ \\
\hline \multicolumn{2}{|c|}{ LSD at $5 \%$} & 2.40 & 0.25 & 0.88 & 15.31 & 0.883 & 0.031 & 0.53 & 0.05 \\
\hline
\end{tabular}


Table 5 Effect of seed hardening on photosynthetic pigments (mg/gm fresh weight of leaves) and carbohydrate content of shoots (mg/glucose/g dry wt.)

\begin{tabular}{|c|c|c|c|c|c|c|c|c|}
\hline \multicolumn{2}{|l|}{ Treatments } & \multicolumn{7}{|c|}{ Parameters } \\
\hline Temp. $\left({ }^{\circ} \mathrm{C}\right)$ & Exposure period (h) & Ch1a & Ch1b & Ch1 $a+b$ & Carotenoids & Reducing sugars & Sucrose & Polysaccharides \\
\hline Control & & $0.563^{e}$ & $0.225^{d}$ & $0.788^{f g}$ & $0.217^{f}$ & $18.26^{e}$ & $32.11^{d}$ & $137.90^{\mathrm{a}}$ \\
\hline \multirow[t]{3}{*}{50} & 0.5 & $0.565^{\mathrm{e}}$ & $0.210^{e}$ & $0.785^{9}$ & $0.222^{\mathrm{ef}}$ & $18.01^{e}$ & $30.92^{d}$ & $140.73^{\mathrm{a}}$ \\
\hline & 1 & $0.580^{d}$ & $0.232^{\mathrm{cd}}$ & $0.812^{e}$ & $0.231^{\text {de }}$ & $24.43^{b}$ & $36.35^{b}$ & $125.62^{c}$ \\
\hline & 2 & $0.603^{c}$ & $0.230^{c d}$ & $0.833^{d}$ & $0.238^{d}$ & $22.37^{\mathrm{cd}}$ & $34.55^{c}$ & $112.06^{d}$ \\
\hline \multirow[t]{3}{*}{60} & 0.5 & $0.581^{d}$ & $0.226^{d}$ & $0.807^{\mathrm{ef}^{f}}$ & $0.239^{d}$ & $22.37^{\mathrm{cd}}$ & $38.07^{\mathrm{b}}$ & $114.14^{d}$ \\
\hline & 1 & $0.642^{b}$ & $0.230^{c d}$ & $0.872^{b c}$ & $0.299^{\mathrm{a}}$ & $27.14^{\mathrm{a}}$ & $46.14^{\mathrm{a}}$ & $89.96^{f}$ \\
\hline & 2 & $0.683^{a}$ & $0.250^{\mathrm{a}}$ & $0.933^{\mathrm{a}}$ & $0.308^{\mathrm{a}}$ & $28.22^{\mathrm{a}}$ & $44.92^{\mathrm{a}}$ & $103.15^{\mathrm{e}}$ \\
\hline \multirow[t]{3}{*}{70} & 0.5 & $0.611^{c}$ & $0.248^{\mathrm{ab}}$ & $0.883^{b}$ & $0.285^{b}$ & $22.55^{c}$ & $38.22^{b}$ & $112.36^{d}$ \\
\hline & 1 & $0.642^{b}$ & $0.241^{b c}$ & $0.859^{c}$ & $0.268^{c}$ & $21.06^{d}$ & $34.57^{c}$ & $113.20^{\mathrm{d}}$ \\
\hline & 2 & $0.617^{c}$ & $0.238^{\mathrm{bc}}$ & $0.855^{c}$ & $0.262^{c}$ & $22.14^{\text {cd }}$ & $31.91^{d}$ & $131.09^{b}$ \\
\hline LSD at $5 \%$ & & 0.014 & 0.011 & 0.020 & 0.009 & 1.32 & 1.76 & 5.07 \\
\hline
\end{tabular}

Carotenoid content showed a significant increase with all treatments except $50{ }^{\circ} \mathrm{C}$ for $0.5 \mathrm{~h}$. The highest value was obtained by exposing the seeds to $60^{\circ} \mathrm{C}$ for $1 \mathrm{~h}$ or $2 \mathrm{~h}$.

Carbohydrate fractions showed that direct reducing sugars were significantly increased for all treatments except the treatment at $50^{\circ} \mathrm{C}$ for $0.5 \mathrm{~h}, 50^{\circ} \mathrm{C}$ for $0.5 \mathrm{~h}$ and $60^{\circ}$ for $1 \mathrm{~h}$ or $2 \mathrm{~h}$.

Sucrose content followed more or less the same trend of reducing sugars with all treatments except the treatment at $70^{\circ} \mathrm{C}$ for $2 \mathrm{~h}$, and treatment at $60^{\circ} \mathrm{C}$ for $1 \mathrm{~h}$ or 2 $\mathrm{h}$ resulted in the highest significant increase.

Polysaccharide content clearly showed an opposite trend to reducing sugars and sucrose. Significant decrease recorded for all treatments except for treatment at $50^{\circ} \mathrm{C}$ for $0.5 \mathrm{~h}$. Maximum decrease was recorded by treatment at $60^{\circ} \mathrm{C}$ for $1 \mathrm{~h}$ followed by $2 \mathrm{~h}$ (Table 5 ).

Table 6 shows the changes of proline, amino acids and protein as well as nucleic acids RNA and DNA. Proline content exhibited significant increment, with the exception for all treatments except for the treatment at $50{ }^{\circ} \mathrm{C}$ for 0.5 . Maximum increase was obtained by the treatment at $60{ }^{\circ} \mathrm{C}$ for $1 \mathrm{~h}$ followed by $2 \mathrm{~h}$.

Amino acids significantly increased with all treatments at $60^{\circ} \mathrm{C}$ or $70^{\circ} \mathrm{C}$. The highest value of increase was obtained by $60^{\circ} \mathrm{C}$ for $2 \mathrm{~h}$ as well as $70^{\circ} \mathrm{C}$ for $1 \mathrm{~h}$.

Protein content exhibited significant increments by all treatments with the exception of two treatments, $50^{\circ} \mathrm{C}$ or $60^{\circ} \mathrm{C}$ for $0.5 \mathrm{~h}$. The highest value of significance was obtained by the treatment at $60^{\circ} \mathrm{C}$ for $1 \mathrm{~h}$ followed by the treatment for $2 \mathrm{~h}$.

Nucleic acid (RNA) recorded a significant increase for most treatments except $50^{\circ} \mathrm{C}$ for $0.5 \mathrm{~h}$ as well as $70^{\circ} \mathrm{C}$ for $1 \mathrm{~h}$ or $2 \mathrm{~h}$. Meanwhile, maximum significant increase was recorded by treatment at $60^{\circ} \mathrm{C}$ for $1 \mathrm{~h}$ or $2 \mathrm{~h}$. DNA content showed a significant increase by the following treatments: $50{ }^{\circ} \mathrm{C}$ for $1 \mathrm{~h}, 60^{\circ} \mathrm{C}$ for $1 \mathrm{~h}$ or $2 \mathrm{~h}$ and $70^{\circ} \mathrm{C}$ for $1 \mathrm{~h}$ (Table 6).

Table 7 shows the effect of heat hardening of tomato seeds on the percentage of fatty acids. The analysis shows an increase of myristic acid percentage, while it shows a decrease of palmitic oleic and palmitoleic

Table 6 Effect of seed hardening on proline, free amino acids, RNA and DNA content of plant shoots

\begin{tabular}{|c|c|c|c|c|c|c|}
\hline \multicolumn{2}{|l|}{ Treatments } & \multicolumn{5}{|l|}{ Parameters } \\
\hline Temp. $\left({ }^{\circ} \mathrm{C}\right)$ & Exposure period (h) & Proline, ug/g fresh wt. & Amino acids, mg/g dry wt. & Proteins, mg/g dry wt. & RNA, mg/g fresh wt & DNA, mg/g fresh wt \\
\hline$\overline{\text { Control }}$ & & $41.22^{9}$ & $7.01^{e f}$ & $29.21^{\mathrm{e}}$ & $1.01^{\mathrm{d}}$ & $0.211^{c}$ \\
\hline \multirow[t]{3}{*}{50} & 0.5 & $42.22^{9}$ & $6.61^{\mathrm{fg}}$ & $28.38^{\mathrm{e}}$ & $0.979^{d}$ & $0.211^{c}$ \\
\hline & 1 & $44.77^{f}$ & $7.22^{\mathrm{e}}$ & $30.00^{\text {de }}$ & $1.07^{c}$ & $0.219^{\mathrm{a}}$ \\
\hline & 2 & $47.25^{\mathrm{e}}$ & $7.43^{\mathrm{de}}$ & $30.95^{\mathrm{cd}}$ & $1.10^{c}$ & $0.214^{\mathrm{bc}}$ \\
\hline \multirow[t]{3}{*}{60} & 0.5 & $49.15^{c}$ & $6.40^{9}$ & $28.55^{9}$ & $1.17^{\mathrm{b}}$ & $0.215^{\mathrm{abc}}$ \\
\hline & 1 & $62.14^{b}$ & $8.11^{\mathrm{bc}}$ & $32.04^{c}$ & $1.23^{\mathrm{a}}$ & $0.218^{\mathrm{ab}}$ \\
\hline & 2 & $64.48^{\mathrm{a}}$ & $9.52^{\mathrm{ab}}$ & $36.05^{\mathrm{a}}$ & $1.19^{\mathrm{ab}}$ & $0.218^{\mathrm{ab}}$ \\
\hline \multirow[t]{3}{*}{70} & 0.5 & $49.33^{\mathrm{e}}$ & $7.95^{\mathrm{cd}}$ & $33.93^{b}$ & $1.09^{c}$ & $0.217^{\mathrm{ab}}$ \\
\hline & 1 & $55.15^{c}$ & $9.92^{\mathrm{a}}$ & $31.45^{c}$ & $1.01^{\mathrm{d}}$ & $0.211^{c}$ \\
\hline & 2 & $52.14^{d}$ & $9.18^{\mathrm{b}}$ & $31.52^{c}$ & $0.966^{\mathrm{d}}$ & $0.212^{c}$ \\
\hline LSD at $5 \%$ & & 2.12 & 0.56 & 1.37 & 0.050 & 0.004 \\
\hline
\end{tabular}


Table 7 Effect of seed hardening on the percentage of fatty acids in plant shoots

\begin{tabular}{|c|c|c|c|c|c|c|c|c|c|c|c|c|}
\hline \multirow{2}{*}{$\begin{array}{l}\text { Treatment } \\
\text { Temp. }{ }^{\circ} \mathrm{C}\end{array}$} & \multicolumn{11}{|c|}{ Percentage of saturated and unsaturated fatty acids ${ }^{a}$} & \multirow{2}{*}{$\begin{array}{l}\text { Percentage } \\
\text { of total } \\
\text { saturated } \\
\text { fatty acids }\end{array}$} \\
\hline & Exposure period (hr) & C12: 0 & C14:0 & C14:1 & C16:0 & C16:1 & C16:2 & C18:0 & C18: 1 & C18:2 & C18:3 & \\
\hline Control & & 0.69 & 1.32 & - & 36.61 & 31.61 & 1.45 & 7.26 & 16.88 & - & 1.86 & 45.88 \\
\hline 50 & 2 & 0.29 & 58.70 & - & 12.85 & 4.99 & 0.93 & 0.97 & 13.82 & - & 3.36 & 72.81 \\
\hline 60 & 1 & 2.81 & 50.64 & 5.07 & 7.00 & 11.45 & 0.64 & 10.26 & 1.51 & - & 2.38 & 70.71 \\
\hline 60 & 2 & 0.07 & 67.43 & 3.14 & 8.21 & 4.47 & 1.23 & 3.89 & 3.98 & 1.82 & 1.10 & 79.60 \\
\hline 70 & 0.5 & 0.30 & 57.94 & - & 11.31 & 11.5 & 0.32 & 0.34 & 10.60 & 3.10 & 1.58 & 69.88 \\
\hline
\end{tabular}

${ }^{a}$ C12:0 lauric acid; C14: 0 myristic acid; C14: 1 nyristoleic acid; C16:0 palmitic acid; C16:1 palmitoleic acid C16: 2 palmitolenic acid; C18: 0 stearic acid; C18: 1 oleic acid; C18: 2 linoleic acid; C18:3 linolenic acid

percentage. Total saturated fatty acid percentage was increased obviously compared to untreated plants. Maximum increments were recorded by treatment at $60{ }^{\circ} \mathrm{C}$ for $2 \mathrm{~h}$.

\section{Discussion}

High temperature is considered one of the most important environmental factors that affect plant growth. It is the most influential factor which induces an increase of plant evaporation demand and indirectly contributes to water deficiency or salt stress (Karim et al. 1998). Seed hardening modulates the physiological and biochemical nature of seeds that lead to induction of the ability of seeds to stand higher temperature for a prolonged period (Sujatha et al. 2013).

It is clear that exposure of seeds to suitable high temperature and period of soaking improved radicale and plumule length as well as seedling fresh weight. However, the increase of temperature and period of exposure caused a harmful effect (Tables 2 and 3). These results coincide with the findings of other investigators (Farooq et al. 2004, 2005; Rehman et al. 2014).

Other researchers stated that seed hardening can modify physiological and biochemical characters that enable seeds to tolerate environmental stress and stand more easily under unsuitable conditions (Matsushima and Sakagami 2013). Increase of radicale and plumule length as well as fresh weight of seedlings indicated many alterations, such as changes within the cytoplasm as hydration of colloids and increase the viscosity and elasticity (Sujatha et al. 2013). Metabolic activity was also suggested by other investigators as soaking of seeds enhancing metabolites (Barsa et al. 2005) and inducing carbohydrate to become ready to be used for cell elongation (Farooq et al. 2006, on rice). All these changes lead to a better start and uniform of the seedling that can endure environmental stress (Farahani et al. 2011). Thus, seed hardening stimulates pregermination metabolic process without protrusion of the radicale through the seed coat (Heydeker 1977) and provides a faster and synchronized germination (Nawaz et al. 2009).
Improvement of vegetative growth represented by enhancement of branching and increase of number and area of leaves as well as fresh and dry weight of tomato leaves and shoots indicates a generally positive effect. Pre-sowing heat hardening of tomato seeds with $50{ }^{\circ} \mathrm{C}$ and $60^{\circ}$ for $1 \mathrm{~h}$ or $2 \mathrm{~h}$ showed the highest increments (Table 4). These results may be attributed to healthy germination of seed, which in turn gave the plant a better start and induced further growth of tomato seedlings. These results were supported by the findings of other researchers (Khalil and Moursy 1983, Gamal El-Din 1999 and El-Moursi et al. 2012) who proved that heat hardening of seeds promoted the growth of different plants. In addition, Souza and Devaraj (2013) reported an accumulation of biomass in heat-acclimated Dilchos libalab under heat stress condition.

Photosynthetic pigments (chlorophyll a, chlorophyll b and carotenoids) were increased by the hardening of tomato seeds. Maximum level was attained by seeds treatment with $60^{\circ} \mathrm{C}$ for $2 \mathrm{~h}$ (Table 5). Lower level of the photosynthetic pigments in control plants reflects the effect of high temperature stress as the ambient temperature above the threshold (43-44). The impairment of chlorophyll accumulation is the first process occurring in the plastids due to high temperature. Anjum et al. (2011) reported that the decrease of chlorophylls under drought stress may be a result of pigment photooxidation and chlorophyll degradation. Other researchers attributed a decrease of chlorophylls to the reduction of their synthesis or acceleration of degradation or combination of both. In support to these finding, Dutta et al. (2009) and Reda and Mandura (2011) showed destruction of numerous enzymes involved in the mechanism of chlorophyll synthesis under high temperature stress. High chlorophyll content due to hardening in the present study improved protection of tomato plants from heat stress as susceptible genotypes showed a higher reduction of total chlorophylls than the tolerant ones (Gosavi et al. 2014 and Zhou et al. 2017). Moreover, other researchers stated that the accumulation of chlorophylls has been used to characterize the 
variability of thermotolerance for many crop species (Selvaraj et al. 2011).

The increase of carotenoids accompanied with high level of chlorophylls in treated plants pointed clearly to the effective role of carotenoids in protecting chlorophylls from the damage of singlet oxygen. Carotenoids scavenge them through directly quenching the excited triplet state of chlorophyll molecule and dissipate as a heat (Pallet and Young 1993). Kuczyriska et al. (2012) reported that xanthophylls play a key role in minimizing the overoxidation in higher plants. Thus, tomato seed hardening increased photosynthetic pigments (ch1s and carotenoids of tomato plant), which in turn minimize the damage of light-absorbing efficiency of photosystems (PSI and PSII) (Murkowski 2001; Langium et al. 2006 and Souza et al. 2004).

Plants use different strategies to maintain osmotic balance as the synthesis and accumulation of soluble sugars, amino acids and proline (Shao et al. 2007 and Hayat et al. 2012).

Reducing sugars as well as sucrose increased by hardening treatments in the present study especially by $60^{\circ} \mathrm{C}$ for $1 \mathrm{~h}$ or $2 \mathrm{~h}$ treatments. On the other hand, the same treatments showed a pronounced decrease of polysaccharide content (Table 5). Other researchers studied the correlation between soluble sugars and polysaccharides in tolerant and sensitive varieties of plants as the tolerant varieties contain high level of soluble sugars especially sucrose concomitant to high activity of sucrosephosphate synthetase compared to sensitive ones (Kerr et al. 1987 and Basu et al. 1991). Previously, Dinar and Rudich (1985) showed an increase of sucrose accompanied by a decrease of starch in a tolerant variety of tomato (Robbin) compared to the sensitive one (Roma). Later, other investigators proved that sucrose has a crucial role in increasing the osmotic potential of stressed cells (Ruan et al. 2010). In addition, Greer and Weston (2010) reported an accumulation of total soluble sugars in heatacclimated varieties of Vitis venefera.

Proline is one of the most important amino acids which were accumulated under stress. The present investigation showed that proline content increased by most of the hardening treatments. Maximum increment was given by $60^{\circ} \mathrm{C}$ for $1 \mathrm{~h}$ followed by exposure for $2 \mathrm{~h}$. Several studies cleared a good relation between proline and increasing tolerance of plants under environmental stresses. These amino acids have different crucial roles act as hydroxyl scavenger, stabilization of membranes and protein structure, as sink for carbon and nitrogen for stress recovery and buffering cellular redox potential under stress (Hayat et al. 2012; Kavikishor and Sreenivasulu 2014 and Yaish 2015). Moreover, Li et al. (2013) reported inducing of tolerance of maize plants under high temperature stress concomitant to accumulation of proline through $\mathrm{P}_{5} \mathrm{C}_{5}(\Delta$ " pyrrolidine-5-carbolate synthesis (2.7.2.11)) using hydrogen sulphide. Other researchers reported that an accumulation of proline under high temperature stress allows the plants to cope with heat stress (Chakraborty and Tongden 2005 and Rasheed et al. 2011).

It is worth to mention that heat stress injury involves water deficit and cell turgor as high temperature cause increases in transpiration and in turn these changes lead to water deficit and increments of loss of turgidity (Cansev 2012).

Protection against dehydration due to high temperature stress can occur via osmoprotectant (soluble sugars, amino acids and proline as these metabolites act as stabilizer of cellular membranes and maintain turgor (Farooq et al. 2008). Many researchers proved that tolerant verities of different plants induced osmolytes as soluble sugars and proline under drought and high temperature. (Arunkumar et al. 2012; Han et al. 2013; Devi and Sujatha 2014 and Solanki and Samangi 2014). Thus, accumulation of soluble sugars and proline are one of the potential biochemical indicators in selecting tolerant cultivars and allowing the plant to cope with heat stress.

Total protein showed significant increase due to heat hardening of tomato seeds and treatment at $60^{\circ} \mathrm{C}$ for $2 \mathrm{~h}$ showed the highest level (Table 6). The same observation was recorded by other researchers (Gulen and Eris 2004 and He et al. 2005). It is worth to mention that tomato plants in the present study were exposed to high temperature during their growth as the ambient temperature reached $\left(30-40^{\circ} \mathrm{C}\right)$ (Table 1$)$.

Nucleic acid (DNA and RNA) contents of tomato shoots (Table 6) were increased due to hardening of seeds. Maximum increase was attained by treatment at $60^{\circ} \mathrm{C}$ for $1 \mathrm{~h}$ or $2 \mathrm{~h}$. The promoting effect of heat hardening overcame the impairment of the prevailing high temperature on tomato plants. Other investigators reported a decrease of DNA and RNA in wheat plants due to high temperature (Sadak and Orabi 2015). Heat stress injury involves water deficit and cell turgor. Other studies showed a decrease of nucleic acid associated with a rise of RNase activity under deficient water supply (Mukherjee and Mukherjee 2015).

High temperature stress induces changes of lipid membranes; it increases their fluidity via decreasing their lipid saturation (Horvath et al. 2012). Thus, it is important to increase the saturation of fatty acids for maintaining stability and enhancement of heat tolerance for membranes (Larkindale and Huang 2004).

The present study showed that heat hardening of seeds increased the percentage of saturated fatty acids treatment at $50{ }^{\circ} \mathrm{C}$ for $2 \mathrm{~h}$ as well as treatment at $60^{\circ} \mathrm{C}$ for 1 $\mathrm{h}$ or $2 \mathrm{~h}$ increased the ratio of saturated fatty acids to 
$72.81 \%, 70.70 \%$ and $79.60 \%$, respectively, compared to control.

Therefore, the present data can illuminate that saturation of fatty acids can share in enhancing heat tolerance of tomato plants (Bita and Gerats 2013 and Ibrahim and El-Moqadam 2015).

\section{Conclusion}

Finally, it can be concluded that heat hardening of tomato seeds with $60^{\circ} \mathrm{C}$ for 1 or $2 \mathrm{~h}$ could alleviate the harmful effect of high temperature prevailing during tomato plants' growth, through the enhancement of their protective parameters such as carotenoids, proline, osmolytes and saturated fatty acids. Thus, this protective mechanism helped the plants to induce their tolerance against high temperature stress, which in turn was reflected on their growth.

\section{Acknowledgments}

The authors are thankful to the National Research Centre for provision of laboratory facilities to carry out this research.

\section{Funding}

There are currently no funding sources in the design of the study and collection, analysis, and interpretation of data and in writing the manuscript.

\section{Availability of data and materials}

The datasets generated and/or analysed during the current study are included in this study.

\section{Authors' contributions}

SKI preformed the laboratory analysis and wrote the paper, and LAE performed the data and coordinated the data collection. Both authors read and approved the final manuscript.

\section{Ethics approval and consent to participate}

Not applicable

\section{Consent for publication}

Not applicable

\section{Competing interests}

The authors declare that they have no competing interests.

\section{Publisher's Note}

Springer Nature remains neutral with regard to jurisdictional claims in published maps and institutional affiliations.

\section{Author details}

'Department of Botany, National Research Centre, Dokki, Cairo, Egypt. ${ }^{2}$ Department of Botany, Girls College of Science, Damam University, Damam, Saudi Arabia.

Received: 27 August 2018 Accepted: 27 March 2019

Published online: 11 July 2019

\section{References}

Anderson JW, Beardall J (1991) Molecular activities of plant cells: an introduction to plant biochemistry. Blackwell Scientific Publications, London, p 264

Anjum SA, Yie X, Wang L, Saleem MF, Man C, Lei W (2011) Morphological, physiological and biochemical responses of plant to drought stress. Afr J Agric Res 6:2026-2032

Arunkumar R, Sairam RK, Deshmukh PS, Pal M, Sangeeta K, Sunll KP, Kashwaha SR, Singh TP (2012) High temperature stress and accumulation of compatible solution in ckickpea (Cicer arietinum L.). Indian J Plant Physiol 17:145-150
Barsa SMA, Farooq M, Tabassum R, Ahmed N (2005) Seed treatment in fine rice (Oryza sativa L.). Seed Sci Technol 33:623-628

Basu PS, Minhas JS (1991) Heat tolerance and assimilate transport in different potato genotypes. J Exp Bot 42:860-861

Bita CE, Gerats T (2013) Plant tolerance to high temperature in a changing environment: scientific fundamentals and production of heat stress -tolerant crops. Front Plant Sci 4:1-18

Boulter D, Barber T (1963) Amino acid metabolism in germinating seed of Vicia faba L. in relation to their biology. New Phytol 62:301-304

Burton K (1956) A study on the condition for the colorimetric estimation of deoxyribonucleic acid. Biochem J 62:315-317

Cansev A (2012) Physiological effect of high temperature treatment on leaves of olive cv. Gemlik. Plant Arch 12:521-525

Chakraborty U, Tongden C (2005) Evaluation of heat acctimation and salicylic acid treatmetns as potent inducers of thermotolerance in cicer arientum $\mathrm{L}$. Curr Sci 89:384-389

Devi SPS, Sujatha B (2014) Drought. Induced accumulation of soluble sugars and proline in two pigeon pea (Cajans Cajanus L. Mill sp.) cultivars. Int J Res Dev 3:302-306

Dinar M, Rudich J (1985) Effect of heat stress on assimilate partitioning in tomato. Ann Bot 56:239-248

Dubios M, Gilles KA, Hamelton JK, Robers PA (1956) Colourimetric method for determination of sugars and related substances. Anal Chem 28:350-356

Duncan DB (1955) Multiple range and multiple F-test. Biometrics 11:1-4

Dutta A, Mohanty S, Tripathy BC (2009) Role of temperature stress on chloroplast biogenesis and protein important in pea. Plant Physiol 150:1050-1061

El-Moursi A, Gamal El-Din KA, Tarraf SA (2012) Physiological response of lupine plant (Lupinus temis L.) to heat hardening. Am Eurasian J Agric Environ Sci 12:660-663

Farahani HA, Moaven P, Maroufi K (2011) Effect of thermopriming on germination of cowpea (Vigna seninsis L.). Adv Environ Biol 5:1668-1675

Farooq M, Barsa SMA, Rehman H, Saleem BA (2008) Seed priming enhances the performance of late sown wheat (Triticum aestivum L.) by improving the chilling tolerance. J Agron Crop Sci 194:55-60

Faroog M, Basra SMA, Ahmed N, Hafeez K (2005) Thermal hardening: a new seed vigor enhancement tool in rice. J Integ Plant Biol 47:187-193

Faroog M, Basra SMA, Hafeez K, Warriach EA (2004) Influence of high and low temperature treatments on the seed germination and seedling vigor of coarse and fine rice. Int Rice Res Notes 29:69-71

Farooq M, Basra SMA, Khalid M, Tabassum R, Mahmood T (2006) Nutrient homeostasis, metabolism of reserves, and seedling vigor as affected by seed priming in coarse rice. Can J Bot 84:1196-1202

Fisher RA (1980) Influences of water stress on crop yield in semiarid regions. In: Turner NC, Kramer PJ (eds) Adaptation of plants to water and high temperature stress. Willey Inter. USA, Pub, pp 323-339

Gamal El-Din KM (1999) Vegetative growth, amino acids and alkaloids changes by heat hardening treatments of Hyoscyamus muticus L. Egypt J Appl Sci 14:216-227

Gosavi GU, Jadhav AA, Kale AA, Godakh SR, Pawar BD, Chimoto VP (2014) Effect of heat stress on proline, cholorophyll content, heat shock proteins and antioxidant activity in sorghum (Sorghum bicolor) at seedling stage. Indian J Biotechnol 13:356-363

Greer DH, Weston C (2010) Heat stress affect growth, sugar accumulation and photosynthesis of Vitis vinifera c.v Semillon grapevines grown in controlled environment. Funct Plant Biol 37:206-214

Gulen H, Eris A (2004) Effect of heat, stress on peroxidase activity and total protein content in strawberry plants. Plant Sci 186:739-744

Han Y, Fan S, Zang Q, Wang Y (2013) Effect of heat stress ton the MDA, proline and soluble sugars content in leaf lettuce seedlings. Agric Sci 4:112-115

Hart JR, Neustadt MH (1957) Application of the Karl Fisher method to gain moisture determination. Cereal Chem 34:26-30

Hayat S, Hagat Q, Ahmed A (2012) Role of proline under changing environments. Plant Signal Behav 1:1456-1466

He Y, Lin X, Huang B (2005) Protein changes in acclimated and non-aclimated creeping bentgrass Agostis Palustris, Hads. J Am Soc Hort Sci 130:521-526

Heydeker W, Joshua A (1977) Alleviation the thermodormancy of lettuce seeds. J Hortic Sci 52:87-98

Horvath I, Glatz A, Nakamoto H, Mishkind ML, Munnk T, Saidi Y (2012) Heat shock response in photosynthetic organisms: membranes and lipid connections. Prog Lipid Res 51:208-220

Ibrahim SK, El-Moqadam L (2015) Improving tolerance of tomato plants (Lycopersicon esculentum Mill) by foliar application of benzyl adenine. Middle East J Appl Sci 5:848-854 
Karim MA, Fracheboud Y, Stamp P (1998) Heat tolerance of maize with reference to some physiological characteristics. Ann Bangladesh Agric 1:27-35

Kavikishor PB, Sreenivasulu N (2014) Is proline accumulation per se correlated with stress tolerance or is proline homeostatis are more critical tissue. Plant Cell Environ 37:300-311

Kerr JL, Kimpel J, Nagao RT (1987) Heat shock gene families of soybean and the regulation of their expression. In: Plant gene system and their biology. Alan R. Liss, Inc., Ny, USA, pp 87-97

Khalil S, Moursy HA (1983) Changes in some germination morphological and reproductive characters of tomato plant as influenced by heat treatments of seeds. Ann Agric Sci Fac Agric Ain Shams Univ Cairo Egypt 28:1099-1121

Kuczyriska P, Latowski D, Niczyporuk S (2012) Zeanthin epoxidation-an in vitro approach. Acta Biochem Polonica 59:105-107

Langium CUI, Jianlong LI, Yamin FAN, Sheng XU, Zhen Z (2006) High temperature effects on photosynthesis, PS II functionality and antioxidant activity of two festuca arundinacea cultivars with different heat susceptibility. Bot Stud 47:61-69

Larkindale J, Huang BR (2004) Thermotolerance and antioxidant systems in Agrostis stolonifera involvment of salicylic acid, abscisic acid, calcium hydrogen peroxide and ethylene. J Plant Phystol 161:405-413

Li ZG, Ding XJ, Du PF (2013) Hydrogen sulphide donor sodium hydro-sulfide improved heat tolerance in maize and involvement of proline. J Plant Physiol 170:741-747

Lowry OH, Rosebrogh NJ, Farr AL, Randall RJ (1951) Protein measurement with folin phenol reagent. J Biol Chem 193:265-275

Matsushima Kl, Sakagami JI (2013) Effects of seed hydropriming on germination and seedling vigor during emergence of rice under different soil moisture conditions. Am J Plant Sci 4:1584-1593

Metzner H, Ran H, Senger H (1965) Untresuchugen zur synchronisier barkit ein zeiner pigment Mangol Mutanten von chloreila. Planta 65:186

Mukherjee S, Mukherjee D (2015) Growth responses and changes in protein and nucleic acids of Cajanus cajan L. under normal, excess and deficient water supply. Int J Agric Innov Res 3:1574-1578

Murkowski A (2001) Heat stress and spermidene affect chlorophyll fluorescence in tomato plants. Biol Plant 44:53-57

Nawaz A, Amjad M, labal J (2009) Effect of thermal hardening on germination and seedling vigour of tomato. J Res (Science) Bahauddin Zakariya Univesity, Multan, Pakistan 10:39-49

Pallet KE, Young AJ (1993) Carotenoids. In: Alscher RG, Hess JL (eds) Antioxidants in higher plants. CRC Press, Boca Raton, Ann Arbor, London, Tokyo, pp 60-89

Rasheed R, Wahid A, Forooq M, Hussain I, Basra SMA (2011) Role of proline and glycinbetadine in improving heat tolerance of sprouting sugarcane (Saccharum sp.) buds. Plant Growth Regul 65:35-45

Reda F, Mandura HMH (2011) Response of enzymes activities, photosynthetic pigments, proline to low or high temperature stressed wheat plant (Triticum aestivum L.) in the presence or absence of exogenous proline or cysteine. Int J Acad Res 3:108-116

Rehman AU, Farooq M, Ali H, Sarwar N, Qamar R (2014) Thermal hardening improves germination and early seedling growth of chickpea. Asian J Agri Biol 2:51-58

Ruan YL, Jin Y, Yang YJ, Li GT, Boyer JS (2010) Sugar input, metabolism and signaling mediated by invertase: roles in development yield potential and response to drought and heat. Mol Plants 3:942-955

Sadak MS, Orabi SA (2015) Improving thermotolerance of wheat plant by foliar application of citric acid and oxalic acid. Int J Chem Tech Res 8:111-123

Schmidt G, Thaunhauser SJ (1945) A method for determination of deoxyribonucleic acid, ribonucleic acid and phosphoproteins in animal tissues. J Biol Chem 161:83-89

Selvaraj MG, Burow G, Burke JJ, Belankar V, Puppala N, Burow MD (2011) Heat stress secreening of peanut (Archis hypoguea L.) seedling for acquired thermotolerance. Plant Growth Regul 65:83-91

Shao HB, Chuc LY, Zang JH, Lua ZH, Hug YC (2007) Change of some antioxidative physiological induces under soil water difficit among 10 wheat (Triticum aestivum L.) genotypes at tillering stage. Colloids Surf B Biointerfaces 54:143-149

Solanki JK, Samangi SK (2014) Effect of drought stress on proline accumulation in peanut genotypes. Int J Adv Res 2:301-309

Souza MR, Devaraj VR (2013) Induction of thermotolerance through heat acclimation in lablab bean (Dilichos lablab). Afr J Biotechnol 12:5695-5704

Souza RP, Machadoa EC, Silva JAB, Lagoa AM, Silveira JAG (2004) Photosynthetic gas exchange chlorophyll fluorescence and some associated metabolic changes in cowpea (Vigna anguiculata) during water stress and recovery Environ Exp Bot 51:45-56

Steel RG, Torrie JH (1966) Principles and procedures of statistics with special references to biological sciences. Mc.Craw- Hill Book Company- Inc- New York, Toronto- London, p 481

Sujatha K, Sivasubramaniam J, Padma J, Selvarani K (2013) Seed hardening. Int J Agric Sci 9:392-412

Taylor AG, Allen PS, Bonnett MA, Bradford KJ, Burris JS, Misra MK (1998) Seed enhancement. Seed Science Research 8(2):245-256. https://doi.org/10.1017/ S0960258500004141

Troll W, Lidsley J (1955) Photometric methods for determination of proline. J Biol Chem 215:655-660

Warrag MOA (1999) Flowering and fruiting of tomato (Lycopersicum esculentum Mill) in Qassin Saudi Arabia during summer. J King Saud Univ Agric Sci 3: $241-250$

Winzler RJ (1955) Methods in biochemical analysis. Interscience, New York, p 270

Yaish MW (2015) Proline accumulation is a general response to abiotic stress in the data palm tree (Phoenix dactylifera L.). Genet Mol Res 14:9943-9950

Zhou R, Kjaer KH, Rosenqvist E, Yu X, Wu Z, Ottosen CO (2017) Physiological response to heat stress during seedling and anthesis stage in tomato genotypes differing in heat tolerance. J Agron Crop Sci 203:68-80

\section{Submit your manuscript to a SpringerOpen ${ }^{\odot}$ journal and benefit from:}

- Convenient online submission

- Rigorous peer review

- Open access: articles freely available online

High visibility within the field

- Retaining the copyright to your article

Submit your next manuscript at $>$ springeropen.com 